\title{
Effect of feeding on morphological skin parameters in pregnant Tushin ewes of North Caucasus
}

\author{
O.K. Gogaev ${ }^{1,2^{*}}$, A.R. Demurova ${ }^{1}$, Y.V. Nakonechnyy ${ }^{1}$, M.D. Basaeva ${ }^{1}$
}

${ }^{1}$ Gorsky State Agrarian University, 362040, RNO-Alania, Vladikavkaz, Kirov Street, 37;

${ }^{2}$ North Caucasus Research Institute of Mining and Foothill Agriculture - a branch of the Federal State Budgetary Institution of Science of the Federal Scientific Center "Vladikavkaz Scientific Center of the Russian Academy of Sciences", 363110, RNO-Alania, Prigorodny district, Mikhailovskoye village, Williams Street, 1.

*Corresponding author email: texmen2@mail.ru;

Journal of Livestock Science (ISSN online 2277-6214) 12: 50-51

Received on 17/10/20; Accepted on 19/12/20; Published on 7/1/2021

doi. 10.33259/JLivestSci.2021.50-51

\begin{abstract}
In 2018, to determine the optimal nutrients rate in the ration required for pregnant ewes in the conditions of distant grazing on mountain pastures of the North Caucasus after the end of the breeding season, 120 Tushin ewes suitable for the third lambing were selected and divided into 4 groups of 30 heads each. Ewes of the first control group were fed the economic ration made in accordance with the standards of All-Russian Research Institute for Animal Husbandry (VIZh) (2003). The ewes' ration in the second, third and fourth groups increased in the total nutritional value by 10,15 and $20 \%$ respectively, compared to the ration of the control group. The study of the skin structure was carried out using preparations made from skin samples of five pregnant ewes from each group. It is found that depending on the season and pregnancy, the skin of test ewes has undergone significant changes: decrease in the thickness of the skin and its layers, the activity of sweat and sebaceous glands, the size of hair follicles and diameter of collagen fiber bundles. The greatest decrease in these indices has appeared in the skin of pregnant ewes, which were fed the ration made according to the standards of All-Russian Research Institute for Animal Husbandry (17.1\%). Similar changes have appeared in the thickness of the epidermis, papillary and reticular layers. The least decrease in the thickness of the skin and its layers has appeared in ewes that were at high feeding level. The study of horizontal sections of the ewes' skin in the test groups showed that the feeding level during pregnancy did not affect the follicles number in the hair group. In ewes that received an increased feeding level, the follicles number per unit area of skin decreased by $8.0-13.9 \%$ due to the increase in fatness and, therefore, skin area.
\end{abstract}

Keyword: feeding level; papillary layer; reticular layer; sebaceous gland; pregnant Tushin ewe. 


\section{Introduction}

Balakirev N.A. et al. note in their work "...Sheep breeding is an industry that ranks second to none in the variety of products and therefore it has huge genetic resources. More than 40 sheep breeds of different types of productivity, which is due to the wide variety of natural and climatic zones are bred in the territory of Russia. At present, due to the country's economic situation over the past twenty years, many sheep breeds in Russia are in danger of extinction, degeneration or are on thin ice, i.e. the breed size shows continuing decline. The problem of preserving the gene pool of farm animals is important, as it is directly related to the production of different products. It is necessary to preserve and maintain all bred sheep breeds in a normal condition, special attention should be paid to native breeds, because they have unique biological qualities and are able to produce different types of products in harsh natural climatic conditions" (Balakirev et al., 2019).

Feeding during pregnancy is of importance to obtain a healthy, strong lamb and increase productivity. At the time of pregnancy hormonal changes occur in the sheep body, during this period the need for energy increases both for the fetus development and for supporting the immune system. The fetus has special requirements for nutrients and metabolic processes that take place in the maternal body (Trukhachev et al., 2018; Trukhachev et al., 2018; Beerman et al., 1995; Duckett et al., 2000; Bazarov et al., 2016; Bazarov et al., 2016; Lamanov et al.,2020; Gogaev et al., 2016). Insufficient nutrients intake affects not only the fetus development but also further productivity, including dairy, which determines the efficiency of rearing young animals ( Gogaev et al., 2001; Gogaev et al., 2003; Gogaev et al., 2012; Gogaev et al., 2014). Feeding correction at the time of pregnancy is relevant, especially under conditions of distant grazing on mountain pastures, which involves breeding such sheep breeds that have more intensive metabolic processes and, accordingly, feed must supply more nutrients (Dvalishvili et al., 2017; Radzhabov et al., 2020; Radzhabov et al., 2020; Gabaev et al., 2016).

According to N.A. Diomidova, "skin differs very favorably from internal organs in that it can be studied without slaughtering an animal, using the method of in vivo sampling. In vivo observations conducted on the same animals made it possible to know the skin properties in relation to changes occurring in the body under the environmental impact" (Diomidova et al., 1957).

One of the main indices that characterize the animal growth and development is changes in the thickness of the skin and its layers during the body vital activity (Gogaev et al., 2020; Gogaev et al.. 2016; Gogaev et al., 2019; Gogaev et al., 2018; Gogaev et al., 2019). The skin is a mirror of the animal health, especially sheep, where it performs the function of producing wool fibers. The aim of the research was to study the impact of the pregnant ewes' feeding level on the morphological skin parameters of Tushin sheep.

\section{Methods and materials}

For the period 2018-2020, studies to determine the optimal nutrients rate in the rations required for pregnant ewes were conducted on the farm "Dzhigkaev Valery Sergeevich" in Ardonsky district of the Republic of North Ossetia-Alania. Coordinates of the farm: latitude-43 11 '38"; longitude-44 18 '49"; altitude - 412 meters. In 2018, after the end of the breeding season, 120 Tushin ewes suitable for the third lambing and selected for the experiment were divided into 4 groups of 30 heads each. Ewes of the first control group were fed the economic ration made in accordance with the standards of All-Russian Research Institute for Animal Husbandry (VIZh) (2003). The ewes' ration in the second, third and fourth groups increased in the total nutritional value by 10,15 and $20 \%$ respectively, compared to the ration of the control group.

The study of the skin structure was carried out in the Gorsky State Agrarian University using preparations made from skin samples of five pregnant ewes from each group on the freezing microtome MZ-2. Skin samples from test ewes were taken in autumn, in November, immediately after insemination, and in February/March, immediately after lambing.

The resulting digital material was processed by the method of variation statistics with the calculus of the corresponding criteria.

\section{Results}

Very little research has been done into the skin structure of pregnant ewes depending on their feeding level. Existing works mainly focuses on the issue of comparative study of the skin structure in the pregnant and dry sheep.

In autumn, the skin of ewes in all test groups was dense and elastic. Vertical sections show a deep and coherent arrangement of hair follicles. The sebaceous and sweat glands are active. The sebaceous glands are large. Sweat glands with wide lumen lie deep and look like convoluted tubes.

Data analysis (table 1) shows that under the impact of season, pregnancy and feeding conditions there was a significant reduction in the thickness of the skin and its derivatives, but the degree of their reduction in the test ewes varies. In ewes of the control group the total skin thickness decreased by $346.7 \mu \mathrm{m}$, or $17.1 \%$, in the test groups, despite the increased feeding level, the total skin thickness decreased by $7.1-12.5 \%$. The lowest decrease in this 
index was observed in ewes that were fed $20 \%$ more nutrients compared to the standards of All-Russian Research Institute for Animal Husbandry. The change in the total skin thickness was followed by changes in the thickness of all its layers, but the nature and degree of changes were unequal.

Table 1 - Thickness of the test ewes' skin and its layers, $\mu \mathrm{m}$

\begin{tabular}{|l|l|l|l|l|l|}
\hline \multirow{2}{*}{ Thickness } & Study period & \multicolumn{2}{l|}{ Groups } \\
\cline { 3 - 6 } & & I (control) & II (test) & III (test) & IV (test) \\
\hline \multirow{2}{*}{ Skin } & at the start of pregnancy & $2031.2 \pm 52.2$ & $2029.8 \pm 55.8$ & $2029.6 \pm 59.4$ & $2031.4 \pm 54.9$ \\
\cline { 2 - 6 } & after lambing & $1684.5 \pm 58.4$ & $1776.4 \pm 42.7$ & $1822.3 \pm 38.1$ & $1886.6 \pm 48.5$ \\
\hline $\begin{array}{l}\text { Including } \\
\text { epidermis }\end{array}$ & at the start of pregnancy & $20.8 \pm 0.59$ & $20.5 \pm 0.48$ & $20.9 \pm 0.47$ & $20.4 \pm 0.46$ \\
\cline { 2 - 6 } & after lambing & $17.8 \pm 0.43$ & $18.5 \pm 0.50$ & $19.4 \pm 0.39$ & $19.8 \pm 0.41$ \\
\hline $\begin{array}{l}\text { Papillary } \\
\text { layer }\end{array}$ & at the start of pregnancy & $1239.0 \pm 44.4$ & $1238.2 \pm 32.2$ & $1238.6 \pm 41.8$ & $1239.4 \pm 42.4$ \\
\cline { 2 - 6 } $\begin{array}{l}\text { Reticular } \\
\text { layer }\end{array}$ & after lambing & $966.4 \pm 24.4$ & $1040.1 \pm 26.2$ & $1089.9 \pm 20.3$ & $1140.2 \pm 25.2$ \\
\cline { 2 - 6 } & at the start of pregnancy & $771.4 \pm 30.3$ & $771.1 \pm 24.3$ & $770.1 \pm 34.1$ & $771.6 \pm 32.6$ \\
\hline
\end{tabular}

Table 2 - Follicles depth and width in test ewes' skin, $\mu \mathrm{m}$

\begin{tabular}{|c|c|c|c|c|c|c|}
\hline \multicolumn{2}{|c|}{ Indices } & \multirow{3}{*}{$\begin{array}{l}\text { Study period } \\
\text { at the start of pregnancy }\end{array}$} & \multicolumn{4}{|l|}{ Groups } \\
\hline & & & I (control) & II (test) & III (test) & IV (test) \\
\hline \multirow{4}{*}{ 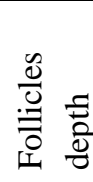 } & \multirow[t]{2}{*}{$\mathrm{PF}$} & & $1259.8 \pm 44.1$ & $1258.7 \pm 38.3$ & $1259.5 \pm 64.4$ & $1259.8 \pm 52.3$ \\
\hline & & after lambing & $984.2 \pm 27.3$ & $1058.6 \pm 26.4$ & $1109.3 \pm 21.9$ & $1160.0 \pm 26.0$ \\
\hline & \multirow[t]{2}{*}{$\mathrm{SF}$} & at the start of pregnancy & $951.1 \pm 29.2$ & $950.3 \pm 37.7$ & $951.1 \pm 41.2$ & $952.4 \pm 39.6$ \\
\hline & & after lambing & $751.4 \pm 20.5$ & $807.8 \pm 16.4$ & $855.9 \pm 16.4$ & $885.7 \pm 17.3$ \\
\hline \multirow{4}{*}{ 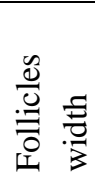 } & \multirow[t]{2}{*}{$\mathrm{PF}$} & at the start of pregnancy & $170.1 \pm 3.4$ & $170.4 \pm 3.0$ & $170.6 \pm 2,6$ & $170.5 \pm 3.6$ \\
\hline & & after lambing & $134.4 \pm 2.2$ & $141.4 \pm 2.4$ & $151.8 \pm 2.9$ & $158.6 \pm 2.7$ \\
\hline & \multirow[t]{2}{*}{$\mathrm{SF}$} & at the start of pregnancy & $89.4 \pm 2.2$ & $89.2 \pm 3.7$ & $89.6 \pm 3.3$ & $89.5 \pm 4.1$ \\
\hline & & after lambing & $67.1 \pm 2.8$ & $71.4 \pm 1.8$ & $77.7 \pm 2.5$ & $82.3 \pm 2.7$ \\
\hline
\end{tabular}

Table 3 - Glandular system in test ewes' skin, $\mu \mathrm{m}$

\begin{tabular}{|c|c|c|c|c|c|c|}
\hline \multirow{2}{*}{\multicolumn{2}{|c|}{ Indices }} & \multirow{2}{*}{ Study period } & \multicolumn{4}{|c|}{ Groups } \\
\hline & & & I (control) & II (test) & III (test) & IV (test) \\
\hline \multirow{4}{*}{ 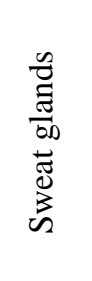 } & \multirow[t]{2}{*}{ depth } & at the start of pregnancy & $\begin{array}{l}1224.5 \pm \\
50.8\end{array}$ & $\begin{array}{l}1226.2 \pm \\
47.6\end{array}$ & $\begin{array}{l}1224.3 \pm \\
53.9\end{array}$ & $\begin{array}{l}1225.1 \pm \\
52.1\end{array}$ \\
\hline & & after lambing & $\begin{array}{l}869.4 \pm \\
28.2\end{array}$ & $\begin{array}{l}968.6 \pm \\
25.5\end{array}$ & $\begin{array}{l}1040.6 \pm \\
24.5\end{array}$ & $\begin{array}{l}1102.6 \pm \\
27.8\end{array}$ \\
\hline & \multirow{2}{*}{$\begin{array}{l}\text { width of the } \\
\text { secretory } \\
\text { division }\end{array}$} & at the start of pregnancy & $69.5 \pm 3.4$ & $69.0 \pm 2.6$ & $66.4 \pm 4.1$ & $68.2 \pm 5.1$ \\
\hline & & after lambing & $52.8 \pm 3.4$ & $55.9 \pm 2.2$ & $57.1 \pm 1.7$ & $62.1 \pm 3.3$ \\
\hline \multirow{4}{*}{ 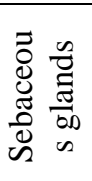 } & \multirow[t]{2}{*}{ length } & at the start of pregnancy & $86.4 \pm 6.7$ & $85.8 \pm 6.6$ & $86.5 \pm 6.2$ & $87.1 \pm 6.6$ \\
\hline & & after lambing & $62.2 \pm 6.5$ & $69.5 \pm 5.4$ & $76.1 \pm 6.4$ & $81.8 \pm 6.9$ \\
\hline & \multirow[t]{2}{*}{ width } & at the start of pregnancy & $46.6 \pm 2.6$ & $45.7 \pm 3.0$ & $45.4 \pm 2.9$ & $46.8 \pm 3.1$ \\
\hline & & after lambing & $35.0 \pm 2.9$ & $37.4 \pm 2.4$ & $40.5 \pm 1.9$ & $44.4 \pm 2.2$ \\
\hline
\end{tabular}

The epidermal thickness in ewes of the first group decreased by $14.4 \%$, while in ewes of the second group such decrease was less significant and ranged from $9.8 \%$ in the second group to $2.9 \%$ in the fourth group.

The greatest changes in the skin thickness occurred in the papillary layer. In all test groups of ewes, the thickness of the papillary skin layer decreased ranging from 8.0 to $22.0 \%$. The most severe thinning occurred in the ewes of the first group (22.0\%), the least - in the counterparts of the fourth group $(8.0 \%)$, in the ewes of the second and third groups the thickness of the papillary layer decreased by 16.0 and $12.0 \%$, respectively. The same pattern was observed when changing the reticular layer of test animals' skin, but it should be noted that the greatest decrease occurred in the thickness of the papillary layer, then in the reticular layer.

Along with a decrease in the thickness of the papillary layer, there were changes in the depth and width of primary and secondary hair follicles. Thus, the depth of primary hair follicles in the ewes' skin during the period of 
pregnancy decreased by $7.9-21.9 \%$ according to the feeding level of all test groups. The same pattern was observed in the depth of secondary hair follicles.

The feeding level of pregnant ewes also affected the size of hair follicles (table 2). Thus, the width of primary follicles in the ewes' skin of the first group decreased by 21.0 ; in the second group - by 17.0; in the third group - by 11.0 and in the fourth - by $6.4 \%$.

A similar decrease is observed in the width of the secondary follicles, which was in ewes of the first group 24.9 ; in the second group -20.0 ; in the third group -13.3 and in the fourth group $-8.0 \%$.

It is known that the sweat and sebaceous glands function most actively in the summer-autumn period, at this time their depth and size are of the greatest value, and, by contrast, in the winter-spring period, their size decreases due to the reduction in their secretory activity, which is confirmed by the data in table 3 . The analysis of the data presented, it can be seen that in all test groups, the depth and width of the secretory divisions in the sweat glands decreased. A more significant decrease in these indices is observed in the ewes of the first control group.

A significant decrease also occurred in the size of the sebaceous glands, the length of which in ewes of the first group was 28.0; in the second group -19.0 ; in the third group -12.0 and in the fourth $-6.1 \%$ of the original length, and the width - by $24.9 ; 18.2 ; 10.8$ and $5.1 \%$, respectively. As these data show, the greatest decrease in the size of the sebaceous glands is observed in pregnant ewes, which were fed the ration made in accordance with the standards of All-Russian Research Institute for Animal Husbandry.

Under the impact of the season and the feeding level of pregnant ewes, the diameter of the collagen fiber bundles decreased. Data from table 4 show that the diameter of collagen fibers in ewes of the first group decreased by an average of $25.9 \%$, while in the test groups this index was: in the second -20.4 ; in the third -16.5 and in the fourth $-10.1 \%(\mathrm{P}>0.99)$

Table 4 - Diameter of skin collagen fiber bundles, $\mu \mathrm{m}$

\begin{tabular}{|l|l|l|}
\hline \multirow{2}{*}{ Group } & \multicolumn{2}{|l|}{ Study period } \\
\cline { 2 - 3 } & $\begin{array}{l}\text { at the start of } \\
\text { pregnancy }\end{array}$ & after lambing \\
\hline I (control) & $13.5 \pm 0.38$ & $10.0 \pm 0.33$ \\
\hline II (test) & $13.7 \pm 0.41$ & $10.9 \pm 0.33$ \\
\hline III (test) & $13.9 \pm 0.30$ & $11.6 \pm 0.32$ \\
\hline IV (test) & $13.8 \pm 0.34$ & $12.4 \pm 0.33$ \\
\hline
\end{tabular}

Table 5 - Follicles number in test ewes' skin, (in pieces/ pcs)

\begin{tabular}{|c|c|c|c|c|c|}
\hline \multirow[t]{2}{*}{ Index } & \multirow[t]{2}{*}{ Period } & \multicolumn{4}{|l|}{ Groups } \\
\hline & & I (control) & II (test) & III (test) & IV (test) \\
\hline \multicolumn{6}{|c|}{ Follicles number in the hair group } \\
\hline \multirow[t]{2}{*}{$\mathrm{PF}+\mathrm{SF}$} & at the start of pregnancy & $12.2 \pm 0.28$ & $12.4 \pm 0.28$ & $12.3 \pm 0.16$ & $12.2 \pm 0.22$ \\
\hline & after lambing & $11.4 \pm 0.31$ & $11.9 \pm 0.34$ & $12.1 \pm 0,24$ & $12.1 \pm 0.34$ \\
\hline \multirow[t]{2}{*}{ PF } & at the start of pregnancy & $1.8 \pm 0.17$ & $1.8 \pm 0.16$ & $1.8 \pm 0.13$ & $1.8 \pm 0.19$ \\
\hline & after lambing & $1.6 \pm 0.60$ & $1.7 \pm 0.50$ & $1.7 \pm 0.51$ & $1.7 \pm 0.47$ \\
\hline \multirow[t]{2}{*}{ SF } & at the start of pregnancy & $10.4 \pm 0.12$ & $10.6 \pm 0.15$ & $10.5 \pm 0.18$ & $10.4 \pm 0.21$ \\
\hline & after lambing & $9.8 \pm 0.31$ & $10.1 \pm 0.33$ & $10.4 \pm 0.22$ & $10.4 \pm 0.30$ \\
\hline \multicolumn{6}{|c|}{ Follicles number per $1 \mathrm{~mm}^{2}$ of skin } \\
\hline \multirow[t]{2}{*}{$\mathrm{PF}+\mathrm{SF}$} & at the start of pregnancy & $28.8 \pm 0.73$ & $28.2 \pm 1.07$ & $28.7 \pm 0.86$ & $28.5 \pm 0.71$ \\
\hline & after lambing & $27.8 \pm 0.69$ & $26.4 \pm 0.67$ & $25.4 \pm 1.23$ & $24.8 \pm 0.83$ \\
\hline \multirow[t]{2}{*}{$\mathrm{PF}$} & at the start of pregnancy & $5.2 \pm 0.13$ & $5.3 \pm 0.15$ & $5.1 \pm 0.15$ & $5.3 \pm 0.18$ \\
\hline & after lambing & $5.1 \pm 0.17$ & $4.9 \pm 0.18$ & $4.7 \pm 0.14$ & $4.5 \pm 0.16$ \\
\hline \multirow[t]{2}{*}{ SF } & at the start of pregnancy & $23.6 \pm 0.60$ & $22.9 \pm 0.79$ & $23.6 \pm 0.76$ & $23.2 \pm 0.69$ \\
\hline & after lambing & $22.7 \pm 0.72$ & $21.5 \pm 0.59$ & $20.7 \pm 0.92$ & $20.3 \pm 0.68$ \\
\hline
\end{tabular}

As the data presented show, the skin thickness and the size of its derivatives are greatly reduced after lambing (February/March). The depth of hair roots is more superficial. They are more curved and lie with a greater gradient to the skin surface. The number of fat cells significantly decreased. The sweat glands do not extend vertically as deeply into the reticular layer, but are inclined to the skin surface. Their secretory divisions in most animals are located below the deep-lying hair follicles.

Studying the horizontal skin sections in all test ewes showed that at the beginning of the experiment, the follicles number in the skin of all test animals was almost equal both in the hair group and per unit area of the skin.

The analysis of table 5 shows that on average, the hair group of adult Tushin sheep contains $11.4-12.4$ follicles, including 1.6-1.8 primary follicles and 9.8-10.6 secondary ones.

Data from table 5 show that the follicles number is less susceptible to changes occurring in the skin of pregnant ewes, under the impact of different feeding levels compared to other morphological skin parameters. Thus, 
the total number of follicles in the hair group ranged from 0.8 to $6.6 \%$. Probably, this phenomenon is associated with the destruction of a part of follicles as a result of nutrients deficiency in the ewes' body.

The total number of hair follicles decreased by 0.8 pcs or $6.6 \%$ in the group of ewes, which received an economic ration made according to the standards of All-Russian Research Institute for Animal Husbandry. In the second group this index decreased by $4.0 \%$, in the third - by $1.6 \%$ and in the fourth - by $0.8 \%$.

Analyzing the number of primary follicles, it can be noted that they are more susceptible to changes and the decrease was $5.5-11.1 \%$. It is also observed that primary follicles greatly decrease in the ewes of the first group. The reverse is observable when analyzing the data on the number of hair follicles per unit area of skin compared to the data of this index in the hair group. If in the hair group, an increased feeding level contributes to the preservation of the follicles number, so, on the contrary, due to an increase in the ration nutritional value, the animal fatness increases with the respective increase in the skin area, and since hair follicles are laid in the embryonic period, the number of follicles per unit of skin area decreases according to an increase in the skin area during the vital activity. So the least decrease in the total number of hair follicles was observed in ewes of the first group, then as the nutrients in the ration increase, the density of hair follicles in the skin decreases. In ewes of the fourth group that received $20 \%$ more nutrients in their rations, the total number of hair follicles decreased by $13.9 \%$, in the third group - by $9.9 \%$ and in the second group - by $8.0 \%$. The same pattern is observed in the number of both primary and secondary hair follicles.

Based on the data obtained, one can conclude that for the period of the experiment, the skin and its layers have undergone the following changes: decrease in the thickness, the activity of sweat and sebaceous glands, the size of hair follicles and diameter of collagen fiber bundles. However, the greatest decrease in these indices has appeared in the skin of pregnant ewes, which were fed the ration made according to the standards of All-Russian Research Institute for Animal Husbandry. During pregnancy, the total skin thickness of ewes decreased by an average of $17.1 \%$, including the epidermis, papillary and reticular layers $(14.4 ; 22.0$ and $9.2 \%$, respectively). The least decrease in the thickness of the skin and its layers has appeared in ewes that were at high feeding level. Their skin thickness decreased by an average of $7.1 \%$, and the layers thickness: the epidermis - by $2.9 \%$; the papillary layer - by $8.0 \%$ and the reticular layer - by $5.8 \%$. In the ewes of the second and third groups the degree of change in the skin structure was intermediate. It should be noted that of all skin layers the greatest decrease occurred in the thickness of the papillary layer, then in the reticular one and the least - in the epidermis; studying horizontal sections of the ewes' skin in the test groups showed that the feeding level during pregnancy did not affect the follicles number in the hair group. This is confirmed by the constant number of hair follicles in the group. In ewes that received an increased feeding level, the follicles number per unit area of skin decreased by $8.0-13.9 \%$ due to the increase in fatness and, therefore, skin area.

\section{References}

1). Balakirev N.A., Yuldashbaev Yu.A., Razumeev K.E., Arylov A.N., Khatataev S.A., Abdulmuslimov A.M. 2019. Selection achievements in domestic sheep breeding / N.A. Balakirev et al. In the collection: Modern engineering problems of key industries, Collection of scientific works of the International scientific and technical symposium and the International Kosygin Forum. Moscow: FSBEI HE “A.N. Kosygin Russian State University" (Technology. Design. Art). 67-70.

2). Trukhachev V.I., Oleinik S.A., Morozov V.Y., Lesnyak T.S., Sklyarov S.P. 2018. The use of innovative remote monitoring methods for growing Manych merino sheep. Research Journal of Pharmaceutical, Biological and Chemical Sciences. 9:1658-1663.

3). Trukhachev V.I., Oleinik S.A., Morozov V.Y., Lesnyak T.S., Sklyarov S.P. 2018. The nutritional value of pasture forage and the assessment of the vegetation index for growing Dzhalginsky merino sheep. Research Journal of Pharmaceutical, Biological and Chemical Sciences. 9:1640-1645.

4). Beerman D.H., Robinson T.F., Hogue D.E. 1995. Impact of composition manipulation on lean lamb production in the United States. Journal of Animal Science 73: 2493-2502.

5). Duckett S.K., Snowder G.D., Cockett N.E. 2000. Effect of the callipyge on muscle growth, calpastatin activity, and tenderness of three muscles across the growth curve. Journal of Animal Science 78:2 836-2841.

6). Bazarov B.M., Rajamuradov Z.T. 2016. Effect of different feeding level karakul sheep in the second half of pregnancy and early lactation on some properties of milk and development of lambs. Eastern European Scientific Journal 1: 9-14.

7). Bazarov B.M., Rajamuradov Z.T. 2016. Change of the milk productivity in karakul sheep under feeding in different level of the feeding and their impact on growth and development of the lambs. European Science Review.5: 7-9.

8). Lamanov A., Ivanov Y., Iskhakov R., Zubairova L., Tagirov K., Salikhov A. 2020. Beef quality indicators and their dependence on keeping technology of bull calves of different genotypes. AIMS Agriculture and Food. 5:1-10.

9). Gogaev O.K., Kessaev K.E., Kaloev B.S., Kebekov M.E., Tarchokov T.T. 2016. The Skin Formation and Hair Coat of the Romanov Sheep in the Conditions of the Piedmont Zone of the North Caucasus. Asian Journal 
of Microbiology, Biotechnology and Environmental Sciences. 18: 1027-1036.

10). Gogaev, O.K. 2001. Use of East-Frisian rams to improve sheep in North Ossetia-Alania. Animal Science. 9: 911.

11). Gogaev, O.K. 2003. Increase in the milk yield of sheep when crossbreeding. Animal Science. 6: 23.

12). Gogaev O.K., Demurova A.R., Morgoeva D.G., Ikoeva D.K., Bideev B.A. 2012. Technological qualities of goat milk. Proceedings of Gorsky State Agrarian University. 49: 144-148.

13). Gogaev O.K., Kesaev Kh.E., Demurova A.R., Ikoeva D.K., Morgoeva D.G. 2014. Dairy productivity of Saanen goats in the conditions of the piedmont zone of RNO-Alania. Proceedings of Gorsky State Agrarian University. 51: 43-48.

14). Dvalishvili V.G. 2017. Different protein levels and productivity of Romanov rams. Proceedings of Gorsky State Agrarian University.54: 69.

15). Radzhabov F.M., Nabotov S.K., Davlatov Kh.K., Galieva Z.A., Akhmetova A.K. 2020. Wool productivity and wool quality of Darvaz fine-fleece ewes at different feeding levels. Agricultural Bulletin of Primorye. 17: 27-30.

16). Radzhabov F.M., Nabotov S.K., Amirshoev F.S., Kosilov V.I. 2020. Growth and development of Darvaz finefleece sheep on seasonal pastures at different levels of energy and protein nutrition. Proceedings of Orenburg State Agrarian University. 1(81): 205-210.

17). Gabaev M.S., Zhashuev Zh.Kh., Gukezhev V.M. 2016. Optimization of ewes' feeding level in resource-saving technology of mountain sheep breeding. International research. 3(28): 354-357.

18). Diomidova, N.A. 1957. Application of the histological method in studying skin and hair follicle ontogenesis. Morphology of sheep skin in relation to their wool productivity. Publishing house of the Academy of Sciences of the USSR. Moscow. 19: 5-23.

19). Gogaev O.K., Demurova A.R., Ikoeva B.K. 2020. Influence of iodine supplements in the Tushin sheep diet on the dynamics of growth in the skin thickness and its layers. Scientific life. 15(3) : 433-440. DOI: $10.35679 /$ 1991-9476-2020-15-3-433-440.

20). Gogaev O. K., Kessaev Kh. E., Demurova A. R., Gatsiev U. S. 2016. Regularities in the formation of skin and hair follicles of young Romanov sheep in the piedmont zone of the North Caucasus. Proceedings of Gorsky State Agrarian University. 53(1): 50-57.

21). Gogaev O.K., Abaev A.A., Demurova A.R. 2019. The patterns of linear skeletal growth of the crossbred sheep. Indo American Journal of Pharmaceutical Sciences. 6(4): 8717-8725.

22). Gogaev O.K. 2018. Postembryonic development of the skin of young Romanov and Tushin ewes under the conditions of the foothill zone in the North Caucasus. Research Journal of Pharmaceutical, Biological and Chemical Sciences. 9(5): 2335-2346.

23). Gogaev O.K., Yuldashbaev Yu.A., Kebekov M.E., Kairov V.R., Kaloev B.S., Demurova A.R. 2019. The features of sheep adaptation to their keeping in mountainous conditions. Indo American Journal of Pharmaceutical Sciences. 6(9): 15653-15661.

Effect of feeding on morphological skin parameters in pregnant Tushin ewes of North Caucasus

O.K. Gogaev, A.R. Demurova, Y.V. Nakonechnyy, M.D. Basaeva 2021. Effect of feeding on morphological skin parameters in pregnant Tushin ewes of North Caucasus. Journal of Livestock Science (ISSN online 2277-6214) 12: 50-51. doi. 10.33259/JLivestSci.2021.50-51 